\title{
The role of SND2 in the regulation of Arabidopsis fibre secondary cell wall formation
}

\author{
Steven Hussey ${ }^{1 *}$, Eshchar Mizrachi ${ }^{1}$, David Berger ${ }^{2}$, Alexander Myburg $^{1}$ \\ From IUFRO Tree Biotechnology Conference 2011: From Genomes to Integration and Delivery \\ Arraial d Ajuda, Bahia, Brazil. 26 June - 2 July 2011
}

\section{Background}

Transcription factors (TFs) play important roles in the regulation of secondary cell wall (SCW) biosynthesis in herbaceous and woody plants. In Arabidopsis, the onset of SCW deposition is initiated by a nexus of NAC, MYB, homeodomain and several other families of TFs, which function in a transcriptional network regulating SCW biosynthetic genes. NAC family members SND1/ NST1 and VND6/VND7 have been identified as functionally redundant master regulators of $\mathrm{SCW}$ formation in fibres and vessels, respectively [1,2]. Arabidopsis plants overexpressing $S N D 2$, an indirect target of fibre master regulator SND1, exhibited increased SCW thickness in inflorescence stem fibres, whilst dominant repression lines exhibited a decrease in fibre SCW thickness associated with a reduction in glucose and xylose cell wall sugar content [3]. The ability of SND2 to transactivate the CesA8 promoter [3] suggested that $S N D 2$ may regulate cellulose biosynthetic genes during fibre SCW formation. The evaluation of this hypothesis necessitates the identification of all downstream genes potentially regulated by $S N D 2$, and the analysis of SCW chemistry and morphology in overexpression lines. The aim of this ongoing study is to further elucidate the role of SND2 in fibre SCW formation through microarray analysis of overexpression lines and by independent confirmation of the effect of SND2 overexpression on fibre SCW chemistry and morphology in Arabidopsis plants.

\section{Methods}

We generated 2x35S::SND2 Arabidopsis thaliana Col-0 plants, screened them for CesA 8 upregulation and phenotypically assessed several homozygous (T4) transgenic

\footnotetext{
* Correspondence: steven.hussey@fabi.up.ac.za

'Department of Genetics, Forestry and Agricultural Biotechnology Institute

(FABI), University of Pretoria, Pretoria, South Africa

Full list of author information is available at the end of the article
}

lines. Inflorescence stem fibre SCW thickness was measured from light and scanning electron micrographs, and the cell wall monosaccharide and Klason lignin composition of stems was determined relative to the wild type. We performed microarray analysis of the inflorescence stem transcriptomes of wild type and transgenic Arabidopsis plants using the Agilent 4x44k transcriptome array and confirmed the expression profiles of differentially expressed genes with RT-qPCR.

\section{Results}

Transgenic Arabidopsis (T4) lines showed no significant external phenotype, and we were unable to reproduce the increased fibre SCW thickness phenotype reported by Zhong et al. [3]. We identified a single homozygous line with CesA8 upregulation and moderate SND2 overexpression. Whole-transcriptome analysis of the line revealed the upregulation of several TFs and genes associated with SCW biosynthesis, which were reproducibly upregulated in an independent trial. We additionally observed possible ectopic artifacts and gene dosage effects associated with excessive constitutive expression of the SND2 gene. Chemical analysis revealed only minor changes in SCW monosaccharides, despite the upregulation of SCW biosynthetic genes.

\section{Conclusions}

Our results implicate $S N D 2$ in the regulation of cellulosic and non-cellulosic components of fibre cell walls, and we provide a model for the position of SND2 in the transcriptional network regulating fibre SCW formation.

\footnotetext{
Author details

'Department of Genetics, Forestry and Agricultural Biotechnology Institute (FABI), University of Pretoria, Pretoria, South Africa. ${ }^{2}$ Department of Plant Science, Forestry and Agricultural Biotechnology Institute (FABI), University of Pretoria, South Africa.
} 


\section{References}

1. Kubo M, Udagawa M, Nishikubo N, Horiguchi G, Yamaguchi M, Ito J, Mimura T, Fukuda H, Demura T: Transcription switches for protoxylem and metaxylem vessel formation. Genes and Development 2005, 19:1855-1860

2. Zhong R, Richardson EA, Ye Z-H: Two NAC domain transcription factors, SND1 and NST1, function redundantly in regulation of secondary wall synthesis in fibers of Arabidopsis. Planta 2007, 225:1603-1611.

3. Zhong R, Lee C, Zhou J, McCarthy RL, Ye Z-H: A Battery of Transcription Factors Involved in the Regulation of Secondary Cell Wall Biosynthesis in Arabidopsis. The Plant Cell 2008, 20:2763-2782.

doi:10.1186/1753-6561-5-S7-P114

Cite this article as: Hussey et al:: The role of SND2 in the regulation of Arabidopsis fibre secondary cell wall formation. BMC Proceedings 20115 (Suppl 7):P114.

\section{Submit your next manuscript to BioMed Central} and take full advantage of:

- Convenient online submission

- Thorough peer review

- No space constraints or color figure charges

- Immediate publication on acceptance

- Inclusion in PubMed, CAS, Scopus and Google Scholar

- Research which is freely available for redistribution

Submit your manuscript at www.biomedcentral.com/submit 